\title{
Governance Evaluation of Listed Mining Companies Based on Entropy Method
}

\author{
SHI Yufang ${ }^{1, \mathrm{a}}$, HUANG Wanli ${ }^{2, \mathrm{~b}}$ \\ ${ }^{1}$ School of Management, Xi'an University of Science and Technology Xi'an, China \\ ${ }^{2}$ School of Management, Xi'an University of Science and Technology Xi'an, China
}

\begin{abstract}
Corporate governance is the basis for correct decision-making and effective management of a company. The sustainable development of a company will depend to a large extent on an effective and reasonable corporate governance structure. The mining industry occupies a fundamental position in China's national economy and plays a very important role. In view of the particularity and importance of the mining industry, this article is based on the research theory of corporate governance, combined with the characteristics of mining companies, and uses the entropy method to conduct targeted and objective corporate governance evaluations. The research concluded that: (1) When the company is in a state of concentrated equity, the incentive and supervision measures adopted for the managers play an obvious role. (2) The larger the independent board of directors, the higher the effectiveness of corporate governance. (3) The larger the board of supervisors, the more meetings, and the more effective corporate governance, the more it can give full play to its supervision and control functions.
\end{abstract}

\section{Introduction}

The mining industry is a basic industry, not only related to the China's social security, but also related to the China's economic security, and has an irreplaceable role in the national economic system. Due to the scarcity, nonrenewability and versatility of mineral resources, they have important strategic significance and special strategic value for ensuring my China's economic security and even national defense security. In the future development process of China, a sufficient supply of mineral resources is needed, and the mining industry is the supplier of mineral resources and an important industry that promotes China's economic growth, especially industrial growth.

With the steady progress of China's "supply-side" reforms in recent years and the implementation of policies such as "de-capacity" and "de-stocking", mining companies are facing unfavorable situations such as falling product prices, weak demand, rising costs, and reduced profit margins. A healthy corporate governance operation model is of great significance for accelerating the improvement of a modern system with a complete range of listed companies in the mining industry, with a reasonable structure, efficient services, and safe and stable. It is urgently required to have a more scientific and complete corporate governance mechanism.

The governance structure and mechanism construction of listed companies in China's mining industry are still relatively imperfect, and there are many hidden problems.
Although most listed companies in the mining industry have established corporate governance structures such as board of directors, board of supervisors, and managers, the functions and interrelationships of these three are not clearly defined, and there is a lot of arbitrariness in their functions. This functional division of labor is not clear, the decentralization and checks and balance mechanisms have not been effectively established, and the role of corporate governance cannot be effectively brought into play.

A good corporate governance structure is an important measure to enhance the brand and establish credibility, and it can also increase the prevention and resolution of risks. Under the influence of various political and economic policies in my China, the establishment of a scientific and complete corporate governance structure for listed companies in the mining industry is not only of great theoretical significance for corporate risk control and efficient management, but also in the practice of healthy and stable development of the mining industry in China Has an urgent need.

\section{Literature review}

Chinese scholars Zhu Hongjun and Wang Hui (2004) ${ }^{[1]}$ showed that relatively concentrated equity may be more effective in protecting the interests of all shareholders and can enhance the value of the company; similarly, Tang Yuejun and Li Weian (2009) ${ }^{[2]}$ also confirmed Such views. 
Wang Yandong (2016) ${ }^{[3]}$ analyzed the relationship between the personal characteristics of executives, corporate governance, and overinvestment, and concluded that as far as state-owned listed companies are concerned, the personal characteristics of executives are more obvious for their overinvestment. effect. Under the current background of the development of listed companies, their internal governance system is not perfect and sound, which also leads to the low corporate governance, which reduces the efficiency of governance to a certain extent.

Ye Chengang, Qiu Li, and Zhang Lijuan (2016) ${ }^{[4]}$ found through empirical research that whether stateowned enterprises or private enterprises, there is a significant positive correlation between corporate governance structure and corporate financial performance.

He Huiqin (2018) ${ }^{[5]}$ studied the relationship between corporate governance and corporate financial performance and found that corporate governance has a positive effect on corporate financial performance, and the higher the manager's ability, the more obvious this effect. However, Wang Geyang, Zhang Zongyi and Song Zengji (2013) ${ }^{[6]}$ studied the relationship between corporate performance and corporate governance and found that there is no obvious evidence that corporate governance can promote corporate value.

In summary, it is not difficult to find that due to the diversification of corporate governance dimensions, although scholars have elaborated on corporate governance-related content from different perspectives, their conclusions are also quite different. At the same time, in the current research, few scholars have studied the role of the board of supervisors in the corporate governance structure. Therefore, this article makes further research on the basis of previous research results, including the board of supervisors into the research scope, hoping to make a better evaluation of the governance level of listed companies in the mining industry.

\section{Construction of Evaluation Index System}

Entropy method is a method that uses the concept of entropy to determine the index weight. The basic idea is to determine the objective weight according to the variability of the index. As an objective weighting method, the entropy method can effectively avoid the subjectivity of the expert scoring method, so that the index can reflect most of the original information. In consideration of making the index weight assignment more objective and retaining more original information of the evaluation index, the entropy method is used to establish a comprehensive evaluation model when modeling. The entropy method is used to determine the weight of each index, and then a comprehensive score is obtained through the weighted index value and weight, so as to comprehensively evaluate the governance of listed companies in China's mining industry.

When selecting indicators, in order to ensure the accuracy and effectiveness of the model, according to the relevant theoretical basis, refer to existing related results, and follow the principles of key, systematic, comparability, accuracy, typicality, and time sequence of indicator selection. Based on the development status of China's mining companies, select the largest shareholder's shareholding ratio (TOP1), the top five largest shareholder's shareholding ratio (TOP5), the size of the board of directors (SD), the size of independent directors (TD), and the size of the board of supervisors of 10 listed companies (SBS), the number of meetings of the board of supervisors (FR) and other indicators to evaluate the level of corporate governance in the mining industry.

\section{Empirical Analysis on Corporate Governance of Listed Companies in the Mining Industry}

\subsection{Sample selection and data sources}

The sample selected in this article is the 2018 data of 10 representative companies selected from China's 74 Ashare mining companies, and the data of ST and PT companies are excluded. The statistical data comes from the CCER China Financial Database, the website of the China Bureau of Statistics and the corresponding original report data, using Excel software to analyze the data.

\subsection{Model design and analysis}

This paper selects the shareholding ratio of the largest shareholder (TOP1), the shareholding ratio of the top five shareholders (TOP5), the size of the board of directors (SD), the size of independent directors (TD), the size of the board of supervisors (SBS), and the number of meetings of the board of supervisors (FR) as Explanatory variables. The entropy method model is used to test it, and the model design is as follows.

Table1. Evaluation indicators of mining companies

\begin{tabular}{|c|c|c|c|c|c|c|}
\hline Corporation & TOP1 & TOP5 & SD & TD & SBS & FR \\
\hline DaYou Energy & $63.04 \%$ & $90.56 \%$ & 14 & 4 & 13 & 12 \\
\hline $\begin{array}{c}\text { China Shenhua Energy } \\
\text { Co. Ltd. }\end{array}$ & $69.45 \%$ & $93.02 \%$ & 10 & 2 & 9 & 9 \\
\hline Shanghai Energy & $62.43 \%$ & $65.51 \%$ & 13 & 3 & 11 & 10 \\
\hline Jizhong Energy & $44.48 \%$ & $76.73 \%$ & 10 & 2 & 9 & 8 \\
\hline $\begin{array}{c}\text { Jingyuan Coal Industry } \\
\text { and Electricity Power } \\
\text { Co.LTD }\end{array}$ & $46.42 \%$ & $58.42 \%$ & 11 & 3 & 9 & 8 \\
\hline WINTIME Energy & $32.41 \%$ & $52.8 \%$ & 9 & 2 & 7 & 5 \\
\hline Panjiang shares & $58.07 \%$ & $61.42 \%$ & 12 & 3 & 9 & 9 \\
\hline
\end{tabular}




\begin{tabular}{|c|c|c|c|c|c|c|}
\hline Pingzhuang Energy & $61.42 \%$ & $64.53 \%$ & 12 & 4 & 9 & 10 \\
\hline LuTian Coal Industry & $59.22 \%$ & $68.17 \%$ & 10 & 2 & 9 & 7 \\
\hline Datong Coal Industry & $57.46 \%$ & $61.16 \%$ & 13 & 3 & 11 & 9 \\
\hline
\end{tabular}

\subsubsection{Index normalization}

$$
X_{i j}=\frac{N_{i j}}{\sum_{i=1}^{n} N_{i j}}(i=1,2,3, \cdots, n ; j=1,2,3, \cdots, m)
$$

Let be the observation data of the j-th index of the i-th sample. Calculate the proportion of the $i$-th evaluation object in the total of the index under the j-th index. The

The new matrix is obtained after standardization, as calculation method is as follows:

Table2. Proportion of research sample evaluation index

\begin{tabular}{|l|c|c|c|c|c|c|}
\hline Corporation & TOP1 & TOP5 & SD & TD & SBS & FR \\
\hline DaYou Energy & 0.1137 & 0.1308 & 0.1228 & 0.1429 & 0.1354 & 0.1379 \\
\hline $\begin{array}{l}\text { China Shenhua } \\
\text { Energy Co. Ltd. }\end{array}$ & 0.1253 & 0.1344 & 0.0877 & 0.0714 & 0.0938 & 0.1034 \\
\hline Shanghai Energy & 0.1126 & 0.0946 & 0.1140 & 0.1071 & 0.1146 & 0.1149 \\
\hline Jizhong Energy & 0.0802 & 0.1108 & 0.0877 & 0.0714 & 0.0938 & 0.0920 \\
\hline $\begin{array}{l}\text { Jingyuan Coal } \\
\text { Industry and } \\
\begin{array}{l}\text { Electricity Power } \\
\text { Co.LTD. }\end{array}\end{array}$ & 0.0837 & 0.0844 & 0.0965 & 0.1071 & 0.0938 & 0.0920 \\
\hline WINTIME Energy & 0.0585 & 0.0763 & 0.0789 & 0.0714 & 0.0729 & 0.0575 \\
\hline Panjiang shares & 0.1047 & 0.0887 & 0.1053 & 0.1071 & 0.0938 & 0.1034 \\
\hline $\begin{array}{l}\text { Pingzhuang } \\
\text { Energy }\end{array}$ & 0.1108 & 0.0932 & 0.1053 & 0.1429 & 0.0938 & 0.1149 \\
\hline $\begin{array}{l}\text { LuTian Coal } \\
\text { Industry }\end{array}$ & 0.1068 & 0.0985 & 0.0877 & 0.0714 & 0.0938 & 0.0805 \\
\hline $\begin{array}{l}\text { Datong Coal } \\
\text { Industry }\end{array}$ & 0.1036 & 0.0883 & 0.1140 & 0.1071 & 0.1146 & 0.1034 \\
\hline
\end{tabular}

\subsubsection{Calculate the entropy value}

In this paper, $Y_{j}$ is used to represent the entropy value of the $\mathrm{j}$-th index, and the calculation formula is as follows:

$$
Y_{j}=-K \sum_{i=1}^{n} X_{i j} \ln \left(X_{i j}\right)
$$

Among them, $\mathrm{K}>0$, In is the natural logarithm, Let the constant $K=1 / \ln (\mathrm{m}), 0 \leq Y \leq 1$.

The $\mathrm{X}_{\mathrm{ij}} \mathrm{li}\left(\mathrm{X}_{\mathrm{ij}}\right)$ obtained from the above matrix is shown in Table 3.

Table3. $\mathrm{X}_{\mathrm{ij}} \mathrm{li}\left(\mathrm{X}_{\mathrm{ij}}\right)$ value table

\begin{tabular}{|l|l|l|l|l|l|l|}
\hline Corporation & TOP1 & TOP5 & SD & TD & SBS & FR \\
\hline DaYou Energy & -0.2472 & -0.2661 & -0.2575 & -0.2779 & -0.2708 & -0.2732 \\
\hline $\begin{array}{l}\text { China Shenhua } \\
\text { Energy Co. Ltd. }\end{array}$ & -0.2602 & -0.2697 & -0.2135 & -0.1885 & -0.2219 & -0.2347 \\
\hline Shanghai Energy & -0.2459 & -0.2231 & -0.2476 & -0.2393 & -0.2482 & -0.2486 \\
\hline Jizhong Energy & -0.2024 & -0.2438 & -0.2135 & -0.1885 & -0.2219 & -0.2195 \\
\hline $\begin{array}{l}\text { Jingyuan Coal } \\
\text { Industry and } \\
\begin{array}{l}\text { Electricity Power } \\
\text { Co.LTD. }\end{array}\end{array}$ & -0.2077 & -0.2086 & -0.2256 & -0.2393 & -0.2219 & -0.2195 \\
\hline WINTIME Energy & -0.1660 & -0.1963 & -0.2005 & -0.1885 & -0.1909 & -0.1642 \\
\hline Panjiang shares & -0.2363 & -0.2149 & -0.2369 & -0.2393 & -0.2219 & -0.2347 \\
\hline Pingzhuang Energy & -0.2437 & -0.2212 & -0.2369 & -0.2780 & -0.2219 & -0.2487 \\
\hline $\begin{array}{l}\text { LuTian Coal } \\
\text { Industry }\end{array}$ & -0.2389 & -0.2282 & -0.2134 & -0.1885 & -0.2219 & -0.2027 \\
\hline $\begin{array}{l}\text { Datong Coal } \\
\text { Industry }\end{array}$ & -0.2349 & -0.2143 & -0.2476 & -0.2393 & -0.2482 & -0.2347 \\
\hline
\end{tabular}


The constant $\mathrm{K}$ can be obtained. In this example, 10 listed mining companies are selected, so $\mathrm{m}=10$, From the formula, is obtained.

According to the entropy formula, we can find: $Y_{1}=0.991645, Y_{2}=0.92906, Y_{3}=0.995921, Y_{4}=0.98465$ $2, \mathrm{Y}_{5}=0.994389, \mathrm{Y}_{6}=0.990385$.

\subsubsection{Calculate the coefficient of difference}

For the $\mathrm{j}$-th index, the greater the difference in the index value, the greater the effect on the evaluation object, the smaller the entropy value. This article defines $G_{j}$ as the difference coefficient of the $\mathrm{j}$-th index, and the calculation formula is as follows:

$$
G_{\mathrm{j}}=1-Y_{\mathrm{j}}
$$

Using the formula and the $\mathrm{Y}_{\mathrm{j}}$ obtained in the previous article, we can find: $\mathrm{G}_{1}=0.008355$, $\mathrm{G}_{2}=0.007094, \mathrm{G}_{3}=0.004079$, $\mathrm{G}_{4}=0.015348, \mathrm{G}_{5}=0.005611, \mathrm{G}_{6}=0.009615$.

\subsubsection{Calculate the index weight}

This paper defines $\mathrm{W}_{\mathrm{j}}$ as the weight of the $\mathrm{j}$-th index, and the calculation formula is as follows:

$$
W_{\mathrm{j}}=\frac{G_{j}}{\sum_{j=1}^{m} G_{j}}(\mathrm{j}=1,2,3, \cdots, m)
$$

It can be obtained by formula $(4): \mathrm{W}_{1}=0.167, \mathrm{~W}_{2}=0.142$, $\mathrm{W}_{3}=0.081, \mathrm{~W}_{4}=0.306, \mathrm{~W}_{5}=0.112, \mathrm{~W}_{6}=0.192$.

When evaluating its governance, based on the information provided, the entropy method is used to calculate the weight of the evaluation index. The shareholding ratio of the largest shareholder (TOP1) accounted for $16.7 \%$, the shareholding ratio of the top five shareholders (TOP5) accounted for $14.2 \%$, the size of the board of directors (SD) accounted for $8.1 \%$, the size of independent directors (TD) accounted for $30.6 \%$, and the size of the board of supervisors (SBS) ) Accounted for $11.2 \%$, and the number of meetings of the board of supervisors (FR) accounted for $19.2 \%$. It can be seen that the size of independent directors (TD) has the largest weight, followed by the number of meetings of the board of supervisors (FR) and the shareholding ratio of the largest shareholder (TOP1), while other indicators have relatively small weights. It can be seen that the size of independent directors, the number of meetings of the board of supervisors, and the shareholding ratio of the largest shareholder have contributed significantly to the corporate governance of mining companies. Therefore, when we make purchase decisions, we consider more important factors such as the shareholding ratio of the largest shareholder of listed companies, the size of independent directors, and the number of meetings of the board of supervisors. This is considered from the perspective of weight.

\subsubsection{Comprehensive score}

As far as this article is concerned, the sum of the product of each company's score and its weight is its comprehensive evaluation value. The formula is as follows:

$$
F_{i}=\sum_{j=1}^{m} W_{j} X_{i j}
$$

According to formula (5), the comprehensive evaluation of governance evaluation of 10 listed mining companies is shown in Table 4:

Table4. Comprehensive evaluation of research samples

\begin{tabular}{|c|c|c|c|}
\hline Corporation & $\begin{array}{c}\text { Overall } \\
\text { Ratings }\end{array}$ & Corporation & $\begin{array}{c}\text { Overall } \\
\text { Ratings }\end{array}$ \\
\hline DaYou Energy & 0.1329 & WINTIME Energy & 0.0680 \\
\hline $\begin{array}{c}\text { China Shenhua Energy } \\
\text { Co. Ltd. }\end{array}$ & 0.0993 & Panjiang shares & 0.1018 \\
\hline Shanghai Energy & 0.1092 & Pingzhuang Energy & 0.1165 \\
\hline Jizhong Energy & 0.0863 & LuTian Coal Industry & 0.0867 \\
\hline $\begin{array}{c}\text { Jingyuan Coal Industry } \\
\text { and Electricity Power } \\
\text { Co.LTD. }\end{array}$ & 0.0947 & Datong Coal Industry & 0.1060 \\
\hline
\end{tabular}

According to the scores of the sample companies in Table 4, the rankings are: Dayou Energy 0.1329 points, Pingzhuang Energy 0.1165 points, Shanghai Energy 0.1092 points, Datong Coal Industry 0.1046 points, Panjiang shares 0.1018 points, China Shenhua Energy Co. Ltd. 0.0993 points, Jingyuan Coal Industry and Electricity Power Co.LTD 0.0947 points, Open Coal Industry 0.0867 points, Jizhong Energy 0.0863 points, and WINTIME Energy Energy 0.0680 points. It can be seen that the higher the level of corporate governance, the higher the company's comprehensive evaluation score.

\section{Research conclusion}

This paper selects 10 representative companies in China's A-share mining industry as the research sample. On the basis of descriptive statistics on the original data, the weight of each indicator is calculated through the entropy method, and then the score of each company is calculated And ranking. Finally, based on the above empirical research results in this paper, the following conclusions are drawn: First, when the company's equity is in a state of concentration, the incentive and supervision measures adopted for the managers play an obvious role. Second, the larger the scale of independent directors, the higher the effectiveness of corporate governance. Third, the larger the board of supervisors and the number of meetings, the more it can give full play to its supervision and control functions, and the more effective corporate governance will be.

For listed companies in the mining industry to continue their operations, they need to improve their corporate governance mechanisms. The company should work hard on the size of independent directors, the number of meetings of the board of supervisors, and the proportion of the largest shareholder, especially the size of independent directors. However, it is not that the larger the scale, the better, but the larger the proportion of independent directors. The stronger the nature, the better the independence of directors, which will promote the selfsupervision of directors, perform their duties independently, and perform their functions independently, so as to form a benign corporate governance mechanism 
and better promote the healthy development of the company.

\section{Acknowledgment}

Fund Project: National Natural Science Foundation of China (51604216)

\section{References}

1. ZHU Hongjun,WANG Hui.Can. "equity checks and balances improve corporate governance?",J. Management world, 2004(10):114-123.

2. TANG Yuejun,LI Wei'an. "Research on the choice preference of large shareholders to governance",J.Journal of financial research, 2009(6):72-85.

3. WANG Yandong. "Personal characteristics, corporate governance and excessive investment of state-owned listed companies" ,J. Communication of finance and accounting, 2016,(36):77-81.

4. YE Chengang, Qiu Li,Zheng Lijuan. "Corporate governance structure, internal quality and corporate financial performance",J. Auditing research, 2016(2):104-112.

5. HE Huiqin. "Corporate governance, manager ability and corporate performance",J. Communication of finance and accounting,2018(5):52-55 .

6. WANG Geyang,ZHANG Zongyi,SONG Zengji. "Empirical analysis of effect of corporate governance on firm performance",J. Journal of Chongqing University, 2013(3):73-80. 